\title{
Erratum
}

\section{Regulation of K-Cl Cotransport: from Function to Genes}

\author{
N.C. Adragna, M. Di Fulvio, P.K. Lauf
}

The oligonucleotides used in our paper (J. Membrane Biol. 201, 109-137; DOI: 10.1007/s00232-004-0695-6) for KCC3 mRNA amplification in vascular smooth muscle cells (VSMCs) were designed based on sequences reported in (Mount et al., 1999). Because the KCC3 sequence described in (Mount et al., 1999) in fact corresponds to KCC4 (see (Mount et al., 1999), note added in proofs), the figure labels and their legends making reference to $\mathrm{KCC} 3$ mRNA expression or regulation in VSMCs should be changed to KCC4. Since, independently, we have shown the presence of $\mathrm{KCC} 3 \mathrm{a}$ and $\mathrm{KCC} 3 \mathrm{~b}$ isoforms and their regulation by the $\mathrm{NO} / \mathrm{sGC} / \mathrm{PKG} / \mathrm{cGMp}$ signaling cascade (Di Fulvio et al. 2003a), this correction does not change the overall interpretation of the data, except that we now conclude that KCC3a, $\mathrm{KCC} 3 \mathrm{~b}$ and $\mathrm{KCC} 4 \mathrm{mRNAs}$ are subjected to regu- lation by the signal transduction pathways originally proposed by us (Di Fulvio et al., 2003a; Di Fulvio et al., 2003b).

\section{Reference}

Di Fulvio, M., Lauf, P.K., Adragna, N.C. 2003a. The NO signaling pathway differentially regulates $\mathrm{KCC} 3 \mathrm{a}$ and $\mathrm{KCC} 3 \mathrm{~b}$ mRNA expression. Nitric Oxide 9:165-71

Di Fulvio, M., Lauf, P.K., Shah, S., Adragna, N.C. 2003b. NONOates regulate $\mathrm{KCl}$ cotransporter-1 and -3 mRNA expression in vascular smooth muscle cells. Am J Physiol Heart Circ Physiol 284:H1686-92

Mount, D.B., Mercado, A., Song, L., Xu, J., George, A.L. Jr., Delpire, E., Gamba, G. 1999. Cloning and characterization of $\mathrm{KCC} 3$ and $\mathrm{KCC} 4$, new members of the cation-chloride cotransporter gene family. $J$ Biol Chem 274:16355-62 